\title{
The Current Situation of the Development of Jilin Shaman Culture Tourism Products
}

\author{
Hua Jin \\ School of Chang chun Sci-Tech University, Chang Chun 130000, China \\ 57615211@qq.com
}

\begin{abstract}
Shaman culture is a unique regional culture, is the essence of the world intangible cultural heritage thick long history. Jilin province is one of the important birthplace of Shaman culture, in-depth analysis of the historical origin, Shaman culture further excavation, protection and inheritance of Shaman culture, has important practical significance and far-reaching the historical significance to build the Shaman culture tourism products in Jilin province. First, the development of cultural tourism products in Jilin Province.
\end{abstract}

Keywords: Shaman culture, tourism product, Jilin Province.

\section{Introduction}

Shaman culture is a unique and charming form in the world's folk cultural heritage. Jilin province is one of the birthplaces of Shamanism culture, many cultural relics such as shaman shaman, folk dance, etc. can be found in Jilin folk. Jilin is a world of Shaman culture "living fossil". At present, the Shaman culture tourism products Changjitu area including ethnic festivals, tourism, museums and Shaman cultural sites. The main ethnic festivals in Jilin province Manchu Folk Culture Festival (Banjin Festival), it is the Manchu family celebrate the day, mainly through the traditional folk dance show, shaman dances performances to attract tourists; The tourist area includes the Longwan Changchun shaman happy garden, which is a large-scale leisure tourism site with the theme of Shaman culture. It is the center of the Chinese shaman cultural heritage base and the research center of Chinese Shaman culture heritage. Contains the shaman performing City, shaman traditional fish skin manufacturing process workshop; animal husbandry. Yitong Valley Tourism Scenic Area, it is an important base for research activities in the world of the shaman, is currently the world's most abundant in content, the most diverse forms of Shaman culture; The Changbai Mountain scenic area, mainly to show the Shaman culture theme sculpture group; shaman style garden, which is composed of the Shaman culture museum, Kamiji, totem pole, is currently the world's most abundant in content, the most diverse forms of Shaman culture show the holy land.

The museum includes the museum and the Changchun University Museum of Yitong Manchu shaman, the Yitong Manchu museum is the only display of Manchu folk cultural relics, historical and folk treasures of professional museum. The Changchun University museum is currently the most professional shaman shaman research base. Shaman culture sites including Jilin Wulajie town and nine stone Shi Guan's family, including Wulajie Manchu generations living place, Shamanism is also an important place for cultural activities, has developed into Wulajie Manchu Han Tun folk village. Nine stone's, Guan's family sacrificial culture site is still retains the shaman family ritual activities.

Shaman culture tourist souvenirs are mainly shaman paper-cut, shaman shaman mask, black mud, fish skin, fish accessories and other items. These goods are mainly concentrated in the scenic spot or scattered in the area. According to the field investigation, it is found that the sales of cultural tourism souvenirs are not optimistic. Meanwhile, it can be seen that the development of cultural tourism souvenirs is an important problem to be solved. Changjitu regional tourism administrative management departments at all levels and not the Shaman culture as a brand, there is no attention with the brand development with the national characteristics of tourist souvenirs. Therefore, the tourism products businesses don't have to spend time and effort to cultivate a professional R \& D personnel, did not employ the Shaman culture scholars to participate, not for innovation, leading to the Shaman culture 
products and other original religious tourism products are basically the same, the lack of market competitiveness.

\section{Jilin province Mr \&matrimonial advantage analysis of tourism product development}

Shamanism is under the condition of the social productivity is very low, of human beings to survive and produce a kind of primitive religion, it has experienced thousands of years in the history of human civilization condenses, forming and becomes more complicated cultural complex. Jilin province of the rich \&matrimonial resources, and the snow and ice eco-tourism supplement each other, become a spectacular cultural landscape, just make up for the better development of sa \&matrimonial tourism products in current jilin province tourism products lack of characteristics of religious culture tourism products, enrich the tourism varieties.

\subsection{Historical origin and the geographical position is suitable for developing \&matrimonial tourism}

Jilin province as one of the birthplace of the manchu, the manchu is the main nationalities believed in shamanism. The manchu for over one thousand years, believed in shamanism has maintained its \&matrimonial asaph the most complete, the most typical.

Manzhu, used to live in the north of jilin area and identified in changbai mountain area is the birthplace of the nation, the jilin province development \&matrimonial tourism has certain persuasive.

\subsection{Mr \&matrimonial deep theoretical research foundation}

The connotation of sa \&matrimonial related academic research mining, in order to better \&matrimonial tourism provides a theoretical basis. Jilin province in recent years, many experts on the shaman \&matrimonial research more deeply, and Mr \&matrimonial charm.

By experts and scholars in the study, make Mr \&matrimonial more life-oriented, specific, more easily accepted by ordinary people and liking. In addition, changchun university, changchun normal university, northeast normal university, jilin normal university and other universities have established the shaman study center and shaman museum, to discover and protect $\mathrm{Mr}$ \&matrimonial made immortal contributions. For long ji figure area to carry out \&matrimonial sa tourism activities to enrich the content of the unique.

\subsection{Jilin province manchu shaman form the most complete preservation}

Jilin province is both \&matrimonial forms of historical heritage, and have a shaman academics tireless research, and many believed in shamanism of ethnic minorities have been living on this piece of land, their customs and habits also has associated with $\mathrm{Mr}$ \&matrimonial. Sa \&matrimonial development of tourism in jilin province can be primitive religious culture, folk culture, natural landscape, combining to form a comprehensive tourism products, improve the competitiveness of jilin province in the tourism market. 
Table 1 Changjitu regional Shaman culture tourism resources list

\begin{tabular}{|c|c|c|}
\hline classification & $\begin{array}{l}\text { Representative } \\
\text { resources }\end{array}$ & Characteristic \\
\hline $\begin{array}{l}\text { National } \\
\text { festivals }\end{array}$ & $\begin{array}{l}\text { Jilin Manchu Folk } \\
\text { Culture Festival } \\
\text { (Banjin Festival) }\end{array}$ & $\begin{array}{l}\text { Manchu Family Celebration Day, show the traditional folk } \\
\text { dance, shaman dances performances. }\end{array}$ \\
\hline \multirow{4}{*}{ tourist area } & $\begin{array}{l}\text { Longwan Changchun } \\
\text { shaman happy garden }\end{array}$ & $\begin{array}{l}\text { The Shaman culture as the theme of large-scale leisure } \\
\text { tourism sites, "China shaman cultural heritage base" and } \\
\text { Chinese shaman cultural heritage research center. The city } \\
\text { contains the shaman performing arts, traditional } \\
\text { manufacturing craft workshop. Shaman skin. }\end{array}$ \\
\hline & $\begin{array}{l}\text { Yitong Valley } \\
\text { Tourism Scenic Area } \\
\text { animal husbandry. }\end{array}$ & $\begin{array}{l}\text { One of the most important bases in the world shaman } \\
\text { research activities, is the world's most abundant content, the } \\
\text { most diverse forms of Shaman culture display base. }\end{array}$ \\
\hline & $\begin{array}{l}\text { Changbai Mountain } \\
\text { scenic spot }\end{array}$ & Shaman culture theme sculpture group \\
\hline & Shaman style garden & $\begin{array}{l}\text { The Shaman culture museum, Kamiji, totem pole, is } \\
\text { currently the world's most abundant in content, the most } \\
\text { diverse forms of Shaman culture show the holy land. }\end{array}$ \\
\hline \multirow{2}{*}{ Museum } & $\begin{array}{l}\text { YitongManchu } \\
\text { Museum }\end{array}$ & $\begin{array}{l}\text { The only display of Manchu folk cultural relics, historical } \\
\text { and folk treasures of the professional museum. }\end{array}$ \\
\hline & $\begin{array}{c}\text { Changchun University } \\
\text { shaman Museum }\end{array}$ & At present, the most professional shaman research base \\
\hline \multirow{2}{*}{$\begin{array}{l}\text { Shaman } \\
\text { culture site }\end{array}$} & Jilin Wulajie town & $\begin{array}{c}\text { Wulajie Manchu generations living place, Shamanism is also } \\
\text { an important place for cultural activities, has developed into } \\
\text { Wulajie Manchu Han Tun folk village. }\end{array}$ \\
\hline & $\begin{array}{l}\text { Table nine's, Guan's } \\
\text { family ritual cultural } \\
\text { relics }\end{array}$ & $\begin{array}{l}\text { At present, it still retains the shaman family worship } \\
\text { activities. }\end{array}$ \\
\hline
\end{tabular}

\section{Analysis of the tourist market of Jilin Province regional Shaman culture tourism}

Shaman culture as the primitive religious culture, it is a mystery. But it is precisely because of its original to modern people is also a great attraction. At the same time, the black land Kanto customs have a mysterious attraction to the South and foreign tourists. Now the tourism industry is a simple process to play. And to pursue the spirit culture as the center of Shaman culture tourism products, not only can satisfy the people regarding the history of folk culture pursuit, but also to participate in the experience, the Shaman culture of fun.

\subsection{The investigation and analysis of the tourist attraction of the Shaman culture tourism products}

Jilin province regional Shaman culture tourist market is divided into two parts at home and abroad, the domestic tourist market accounted for the entire market share of $80 \%$, mainly in the Northeast tourist market; foreign tourist market accounted for the total market share of $20 \%$. In the Northeast tourist market, tourists in Jilin Province, accounting for about $40 \%$ of the total domestic tourist market. In the Shaman culture tourism tourists to young people, but because they know little about the Shaman culture, plus the scenic spot in the culture propaganda in place and explain, many tourists often fly in tourism the process of scenic area, leading to the satisfaction of the tourists is low, the Likert 5 scale statistics, the average satisfaction of tourists is only 2.83 , has not reached the average value. In addition many Shaman culture tourism products due to the development, promotion, management and other aspects of the problem, the Shaman culture tour did not get better development, including the Jilin Province, many potential tourists do not know the Shaman culture tourism has been developed, even 
the root of the primitive culture is not understood. Figure 1 for tourists to the Shaman culture to understand the situation of the questionnaire survey, respondents were the Han nationality. As can be seen from the chart, at the age of 25 -30 years of age, don't fully understand the shaman although less, but after investigation, this phase of the group for the understanding of the Shaman is often from the TV camera shaman. Shaman culture in the modern consciousness, especially at the age of 40-50 years of age, do not understand the basic of Shaman culture, and this stage is in career stage, economic conditions and physical conditions are better, in a narrow sense is the best tourist market. They not for Shaman culture understand, is undoubtedly the Shaman culture tourism market loss. Therefore, the Shaman culture tour of the new tourist attraction is not big.

\subsection{The investigation and analysis of the tourist market of the shaman tourist attractions}

Jilin Province has completed the development and opening of the tourist area is only Changchun Longwan shaman fun park and Yitong Valley animal husbandry. Changchun, Longwan, as the example of the shaman happy garden, mainly recreational tourism activities, the scenic area has a good accommodation, catering, entertainment facilities. $70 \%$ of the tourists in the scenic area overnight, which relates to the objective - leisure time factors in tourism activities, it is doomed to the traffic in the area of imbalance, tourists often choose to travel activities on weekends or national holidays. According to the Longwan Changchun shaman fun park staff, weekend trips to the average daily traffic of about 400 people, usually is very small. At the same time, because the tourists on the new Shaman culture tourism attraction is not big, so Changchun Longwan shaman fun park from operating since 2005, although the traffic is rising, but the increase speed is not ideal. At the same time, for those who have already experienced the Shaman culture and art of tourists, often due to the different personality, Shaman culture tourism activities also have different attitudes. Choleric and sanguine, lively and full of go tourist enthusiasm, generally do not love the same thing, but relatively speaking, phlegmatic and melancholic often introverted, love is familiar, but the number of tourists is less, can not become the main part of potential tourists.

\section{Summary}

To sum up, attracting shaman Jilin Province regional cultural tourism products to tourists is not ideal, at the same time, the majority of tourists to local residents, is completely in the form of domestic production, and did not open large tourism market.

\section{Acknowledgements}

This research was financially supported by the "Much starker choices-and graver consequences-in"social science research of jilin province department of education (Grant No.[2016]588).

\section{References}

[1] Su Donghai. The International Eco Museum and the practice of [J]. China movement of Chinese Museum, 2001 (2). Liu Housheng. Study on the Manchu Shamanism divine words thought connotation and artistic charm of national [J].1997 (6)122-135.

[2] Su Donghai. The International Eco Museum and the practice of [J]. China movement of Chinese Museum, 2001 (2)98-125.

[3] The inheritance and development of Shaman culture in modern tourism activities in Jilin province [D]. 1997 (6). Master Thesis of Northeast Normal University, (5)196-225.

[4] Tourism planning [Z]. Jilin Changbai government network (http://www.chang-baishan, gov.cn)184-205.

[5] http:// baidu.com/jlyanghu/blog. 